\title{
Agricultural byproducts-based biosorbents for purification of bioalcohols: a review
}

\author{
Ravi Dhabhai, Catherine H. Niu* and Ajay K. Dalai
}

\begin{abstract}
For the purification of alcohols derived from microbial fermentations, extensive processing is required. Adsorption is described as one of the most cost-effective and efficient techniques for the separation of water and purification of alcohols. Biobased sorbents (called biosorbents) are advantageous for dehydration of alcohols as they can be developed from cost-effective feedstocks such as waste agricultural biomass or byproducts, have adsorption capacities at par with chemical adsorbents, and can be safely disposed. Alternatively, the spent adsorbents can be reused for fuel or energy production. Agricultural byproducts are low cost and abundantly available materials containing cellulose, hemicellulose, proteins, and lignin as their constituents. Biosorbents have the capability to adsorb water by the polar interaction of their hydroxyl, carboxyl, carbonyl, and amine groups with water molecules. The pore size distribution and thermal stability of biosorbents are also industrially relevant features. They are a promising option to be used in industries for dehydration of alcohols. This paper reviews adsorptive purification of bioalcohols with a focus on using biosorbents, and describes their structure, global availability, water adsorption mechanism, and the use of biosorbents in liquid phase and vapor phase adsorption systems for the purification of ethanol, butanol, and other higher alcohols.
\end{abstract}

Keywords: Adsorption, Biosorbents, Alcohol dehydration, Pressure swing adsorption, Purification

\section{Introduction}

Globally, energy scarcity is a major problem and it is increasing with increasing population and number of vehicles. The transportation sector relies on fossil fuels, so vehicular emissions and associated environment change due to excessive usage of petroleum are a major concern. This has led to the in-depth research for development of environment friendly and possibly cost-effective alternatives. Liquid biofuels such as bioalcohols are alternative energy sources to fossil fuel. However, ethanol, butanol, methanol, isopropanol and other alcohols, produced by microbial fermentation, need intensive purification to obtain fuel grade purity (Niu et al. 2014). The traditional processing techniques have limitations, such

*Correspondence: catherine.niu@usask.ca

Department of Chemical and Biological Engineering, University of Saskatchewan, Saskatoon, SK S7N 5A9, Canada as operating cost, energy requirement, process efficiency and scale up (Prakash et al. 2016; Balat 2011).

Recent technological advancements in production, processing and transportation, coupled with the development of novel substrates, make bioethanol a choice as a gasoline additive worldwide. Furthermore, in the last few years, biobutanol is also gaining significant scientific attention because of its superior fuel properties over ethanol (Abdehagh et al. 2014). Table 1 presents the comparison of the properties of different fuels. Both bioethanol and biobutanol have excellent characteristics as fuel additives because they enhance the quality of gasoline.

The total world bioethanol production in 2016 was a little over 100 billion litres. USA and Brazil are two of the largest producers of bioethanol ( $>85 \%$ of global ethanol production) in the world followed by European Union, China, and Canada (RFA 2017). Currently, butanol is mainly produced from thermochemical route using petroleum, with a global capacity of 2.8 million 
Table 1 Comparison of fuel properties of different fuels [Refs. (Kiss et al. 2016; Balat 2011; Prakash et al. 2016)]

\begin{tabular}{|c|c|c|c|c|c|c|c|}
\hline Property & Gasoline E10 & Methanol & Ethanol & n-Butanol & 2-propanol & Hydrogen & Electricity \\
\hline Chemical structure & $\begin{array}{l}\text { C4 to C12 and } \\
\text { ethanol } \leq 10 \%\end{array}$ & $\mathrm{CH}_{3} \mathrm{OH}$ & $\mathrm{C}_{2} \mathrm{H}_{5} \mathrm{OH}$ & $\mathrm{C}_{3} \mathrm{H}_{8} \mathrm{OH}$ & $\mathrm{C}_{3} \mathrm{H}_{8} \mathrm{O}$ & $\mathrm{H}_{2}$ & $\mathrm{~N} / \mathrm{A}$ \\
\hline Feedstock & Crude oil & $\begin{array}{l}\text { Natural gas, coal, } \\
\text { or, woody } \\
\text { biomass }\end{array}$ & $\begin{array}{l}\text { Corn, grains, or } \\
\text { agri waste } \\
\text { (cellulose) }\end{array}$ & $\begin{array}{l}\text { Corn, grains, or } \\
\text { agri waste } \\
\text { (cellulose) }\end{array}$ & $\begin{array}{l}\text { Corn, grains, or } \\
\text { agri waste } \\
\text { (cellulose) }\end{array}$ & $\begin{array}{l}\text { Natural gas, } \\
\text { methanol, and } \\
\text { electrolysis of } \\
\text { water }\end{array}$ & $\begin{array}{l}\text { Coal, nuclear, } \\
\text { natural gas, } \\
\text { hydroelec- } \\
\text { tric, wind } \\
\text { and solar }\end{array}$ \\
\hline Boiling point $\left({ }^{\circ} \mathrm{C}\right)$ & $35-200$ & 64.7 & 78.4 & 117.7 & 82.6 & $\mathrm{~N} / \mathrm{A}$ & $\mathrm{N} / \mathrm{A}$ \\
\hline $\begin{array}{l}\text { Energy content } \\
\text { (lower heating } \\
\text { value) (BTU/ } \\
\text { gallon) }\end{array}$ & $\begin{array}{l}112,114 \\
-116,090\end{array}$ & 57,250 & 76,330 & 99,837 & - & 51,585 & 3414 BTU/kWh \\
\hline $\begin{array}{l}\text { Energy content } \\
\text { (higher heating } \\
\text { value) (BTU/ } \\
\text { gallon) }\end{array}$ & $\begin{array}{l}120,388 \\
-124,340\end{array}$ & 65,200 & 84,530 & 108,458 & - & 61,013 & 3414 BTU/kWh \\
\hline Physical state & Liquid & Liquid & Liquid & Liquid & Liquid & Compressed gas & N/A \\
\hline $\begin{array}{l}\text { Pump octane } \\
\text { number }\end{array}$ & 84-93 & 112 & 110 & 87 & - & $130+$ & $\mathrm{N} / \mathrm{A}$ \\
\hline Flash point $\left({ }^{\circ} \mathrm{C}\right)$ & -43 & 11 & 13 & 35 & $12-25$ & $\mathrm{~N} / \mathrm{A}$ & N/A \\
\hline $\begin{array}{l}\text { Autoignition tem- } \\
\text { perature }\left({ }^{\circ} \mathrm{C}\right)\end{array}$ & 257 & 480 & 434 & 385 & - & $565-582$ & $\mathrm{~N} / \mathrm{A}$ \\
\hline
\end{tabular}

tons of petro-butanol, equivalent to $\$ 5$ billion (Huang et al. 2014). As per the current worldwide fuel ethanol standards (Table 2), >99 wt.\% purity is required for fuel applications.

There are several processes for the purification of alcohols and production of anhydrous alcohols, such as azeotropic and extractive distillation (Zhao et al. 2017), absorption (Fei and Hongzhang 2009), gas stripping (Schläfle et al. 2017); pervaporation (Bello et al. 2014; Xu et al. 2018); solvent extraction (Lemos et al. 2017), and adsorption (Farzaneh et al. 2017; Pal et al. 2017; Raganati et al. 2018). Combination of one or more of these methods can also be employed to enhance the efficiency of the process. Generally, to get anhydrous (>99\%) ethanol, at first, distillation is carried out to get a purity of $72-92 \%$ (the azeotrope concentration is $95.6 \mathrm{wt} \%$ ), followed by adsorption to remove rest of the water. The energy consumption of this combined process is about $3.9 \mathrm{MJ} / \mathrm{kg}$ compared with that of the single distillation processes (in the range of 6-9 MJ/kg) (Sun et al. 2007).

For biobutanol production, acetone-butanol-ethanol (ABE) fermentation is the most common method

Table 2 Fuel ethanol standards for major ethanol producing countries/region. Modified from Refs. (Costenoble 2017; Kumar et al. 2011, ASTM D4806)

\begin{tabular}{|c|c|c|c|c|c|}
\hline Characteristic & EU & Brazil & USA & Canada & India \\
\hline Ethanol content (vol.\%) & 98.7 & 99.6 & 92.1 & 98.75 & 99.5 \\
\hline Water content, max. (vol.\%) & 0.3 & & $>1$ & 0.1 & 0.1 \\
\hline Methanol max. (vol.\%) & 1 & & 0.5 & & 0.3 \\
\hline Inorganic chloride content max. (ppm) & 20 & & 40 & & \\
\hline Halogen max. (ppm) & & 1 & & 10 & \\
\hline Acidity (as acetic acid), max. (mg/l) & $7 w t \%$ & 30 & 7 & 30 & 30 \\
\hline Copper content, max. (mg/kg) & 0.1 & 0.07 & 0.1 & 0.1 & 0.1 \\
\hline $\mathrm{pH}$ & $6.5-9.0$ & & $6.5-9.0$ & & \\
\hline Density at $20^{\circ} \mathrm{C}\left(\mathrm{kg} / \mathrm{m}^{3}\right)$ & & 791.5 & 789 & 789 & 796 \\
\hline Electrical conductivity max. ( $\mu \mathrm{S} / \mathrm{m})$ & & 500 & & & 300 \\
\hline Appearance & Clear and bright & Clear and impurity free & Clear and bright & & Clear and bright \\
\hline
\end{tabular}


employed. The fermentative yield of butanol is in the range of $2-4 \%$ vol. Furthermore, the broth contains acetone and ethanol and possibly other toxic intermediates (Sánchez-Ramírez et al. 2015). To get fuel grade purity (>99\%) of butanol, several rounds of distillation and decantation are required. The most common dehydration processes presently used in industries are azeotropic distillation, extractive distillation, and pressure swing adsorption. Azeotropic and extractive distillation methods are very energy intensive. To improve the efficiency and cost-effectiveness, hybrid processes are employed (Xue et al. 2014). Table 3 provides a simple comparison of energy requirements of different separation methods to purify butanol. Adsorption is one of the most costeffective methods for ethanol and butanol purification. Therefore, most industrial dehydration processes employ adsorption (selective adsorption of either water or alcohol) after the first round of distillation from dilute fermentation broths (Vane 2008; Jeong et al. 2012).

Adsorbents are natural or synthetic materials of amorphous or microcrystalline structure. Commonly used are molecular sieves, activated carbon, activated alumina, and silica gel on industrial scale (Perry 1997). Adsorbents can be classified based on their structure-amorphous or structured. Structured adsorbents such as molecular sieves zeolites (3A, 4A, 5A, 13X), as their name suggests, possess well-defined ordered structure and homogenous pore size, while amorphous adsorbents including activate carbon, silica gel, activated alumina, and different biosorbents have heterogeneous surface (Perry 1997). Biosorbents have the highest structural heterogeneity and a wide range of pore sizes to cater to their biological function in nature (Isaac et al. 2015). Biosorbents are also commonly used for dye, heavy metals, or antibiotics removal (Malik 2003; Crini 2006; Yan and Niu 2017a) due to their abundant availability, negligible cost, and their excellent capability to adsorb above mentioned components.

The present mini-review describes the purification of bioalcohols (mainly bioethanol and biobutanol) after initial azeotropic distillation followed by adsorptive dehydration to fuel grade purity (>99 wt\%.). There are number of review articles for the use of biosorbents for adsorption of dyes or heavy metals (Gupta and Suhas 2009; Bharathi and Ramesh 2013); however, as per the authors' knowledge, there is no review article on the use of agricultural byproducts-based materials as adsorbents for bioalcohol dehydration. The focus of this paper is thus limited to the description of agri-based materials as adsorbents.

\section{Adsorptive dehydration of bioalcohols}

The adsorption process is one of the most commonly employed process in industries for ethanol dehydration as it is efficient and cost-effective. In a typical adsorption process, the component(s) of choice gets separated from a fluid mixture using an adsorbent material. As indicated before, adsorption is most commonly applied after the initial distillation of alcohols for selective water (or alcohol) adsorption from the water-alcohol mixtures. The adsorption of water on adsorbent is generally of physical nature which is an equilibrium-dependent process expressed by constructing isotherms. By comparing isotherm data at different temperatures, valuable information about the adsorption capacities and system design can be obtained.

The adsorbent must have a high surface to volume ratio; as generally, only a few layers of molecules are adsorbed on the surface. Biosorbents contain polar groups which strongly adsorb polar water. The more the polar groups

Table 3 Energy requirement to separate acetone-butanol-ethanol from fermentation broth using different recovery techniques [Refs. (Abdehagh et al. 2013; Huang et al. 2014; Raganati et al. 2018]

\begin{tabular}{lll}
\hline Recovery process & Butanol concentration jump (wt\%) & Energy consumption (MJ/kg $\mathbf{b u t a n o l}^{\text {) }}$ \\
\hline Hybrid process gas stripping/distillation & From 0.78 to pure \\
Gas stripping/pervaporation/distillation hybrid process & From 1 to $>99.5$ & 21 \\
Extraction/distillation & From 2.2 to 92 & 23 \\
Pervaporation/distillation & From 1 to pure \\
Adsorption/drying/desorption & From 2 to 98 \\
Liquid-liquid extraction & From 1.8 to 99.5 \\
Gas stripping/absorption/distillation & From 1.8 to 99.5 \\
Distillation & From 1 to 99.99 \\
Gas stripping & From 1 to $50 \%$ \\
Extraction & From initial to $75 \%$ butanol removal \\
Pervaporation & Remove 25\% of butanol from the solution & 3.4
\end{tabular}


on adsorbent, the more will be the water adsorption (Kidnay et al. 2011). The ideal adsorbent has high adsorption rate and capacity, high selectivity for the desired component, and low cost. All these characteristics allow for effective separation of the desired component from all other components present in the adsorption feed stream. The ease of desorption is another important factor to be considered to develop an efficient process (Abdehagh et al. 2013, 2016, 2017).

In addition to the adsorption capacity of a given adsorbent, its kinetic performance is also of great significance for the industrial application. In a fixed-bed system, breakthrough curves can be constructed (Qiu et al. 2009). The plots of relative adsorbate concentration $\left(C / C_{0}\right)$ vs. time are termed as breakthrough curve which is studied for each adsorbing species (water, ethanol, or other components present in system). The breakthrough time of an adsorbent is an important criterion in an industrial operation. Alcohol feed concentration affects breakthrough time. The primary reason for shorter breakthrough times with increasing water concentration is that the adsorbent is exposed to more adsorbate per unit time (Pruksathorn and Vitidsant 2009). Furthermore, the adsorbate adsorption rate is also a critical factor.

For water adsorption on to the adsorbent surface, two different routes are commonly employed-liquid phase and vapor phase. Liquid phase adsorption is generally employed to screen an adsorbent for water adsorption capacity but has a disadvantage of leaching of biomass components into the solution which may be undesirable for product purity, while the vapor phase adsorption is favored as continuous operation is possible with high product purity.

Pressure swing adsorption (PSA) is one of the most commonly used processes for dehydration of gas/vapor phase as it is energy and cost-effective (Jeong et al. 2012; Simo 2013). The other reason that PSA is more favored than a similar process such as temperature swing adsorption, as it is easier and quick to switch from high to low pressure and vice versa as compared to temperature, leading to shorter cycles and prolonged life of adsorbent. Originally, the PSA process was invented by Skarstrom (1960), adsorption and desorption/purge steps are carried out in two separate adsorbent beds operated sequentially, enabling a continuous processing. PSA is a cyclical process consisting typically of two or more vessels packed with the adsorbent. The high partial pressure of component to be removed translates to high adsorption capacity (Simo 2013).

A typical PSA cycle for ethanol dehydration is presented in Fig. 1a (Simo 2013). It consists of a pressurization step (production step) in which vapor flows into the column at a high pressure; water is adsorbed while alcohol vapor passes through and collected as product at the bottom of bed. It is followed by regeneration (desorption), as the bed must be regenerated and prepared for the next cycle. It is referred to as blowdown step and occurs at low pressure which is followed by purge to desorb water from the bed under a lower pressure or vacuum. Near the end of the purge step, a portion of product vapor ( $>99 \%$ alcohol) is used to purge the vessel to remove the adsorbed water that had been adsorbed during the production step. Then, the column is re-pressurized with product ethanol vapor from the operating vessel. This completes one cycle and the system is ready to enter a new production step (Jeong et al. 2012; Simo 2013). Pressure profile during a two bed PSA is presented in Fig. 1b. The most common cycle time for an industrial two bed PSA is 6-8 min as seen in Fig. 1b.

During the adsorption, there are three zones in an adsorbent bed namely: (1) the equilibrium zone, where the adsorbate on the adsorbent is in equilibrium with the adsorbate in the inlet fluid phase and no additional adsorption occurs; (2) the mass transfer zone (MTZ), the volume where mass transfer and adsorption take place; (3) the active zone, where no adsorption has yet taken place (Ladisch 1997). It is desirous to reach equilibrium (saturation) in minimum possible time, so a shorter MTZ is desirable (without the mass transfer limitation, the thickness of MTZ would be zero).

To maximize bed capacity, the MTZ needs to be as small as possible because the zone holds only about $50 \%$ of the adsorbate held by a comparable length of adsorbent at equilibrium. To minimize the thickness of MTZ and to make effective use of adsorbent bed, tall and slender beds and smaller particles size of adsorbent bed are recommended. However, smaller particle size, deeper beds, and increased gas velocity will increase pressure drop (Ladisch 1997). Type 3A molecular sieve (MS) is more efficient for drying the ethanol-water azeotrope than type 4A MS due to that the former can be more efficient than the later in terms of excluding ethanol molecules while adsorbing water molecules. In addition, the regeneration energy requirements for type 3A MS are lower than those of type 4A MS (AlAsheh et al. 2004). However, for both of the two types of adsorbents, the temperature required for regeneration of the water saturated bed is high (around $190{ }^{\circ} \mathrm{C}$ or higher), which is energy intensive. There is an incentive to develop cost-effective adsorbents and processes. 

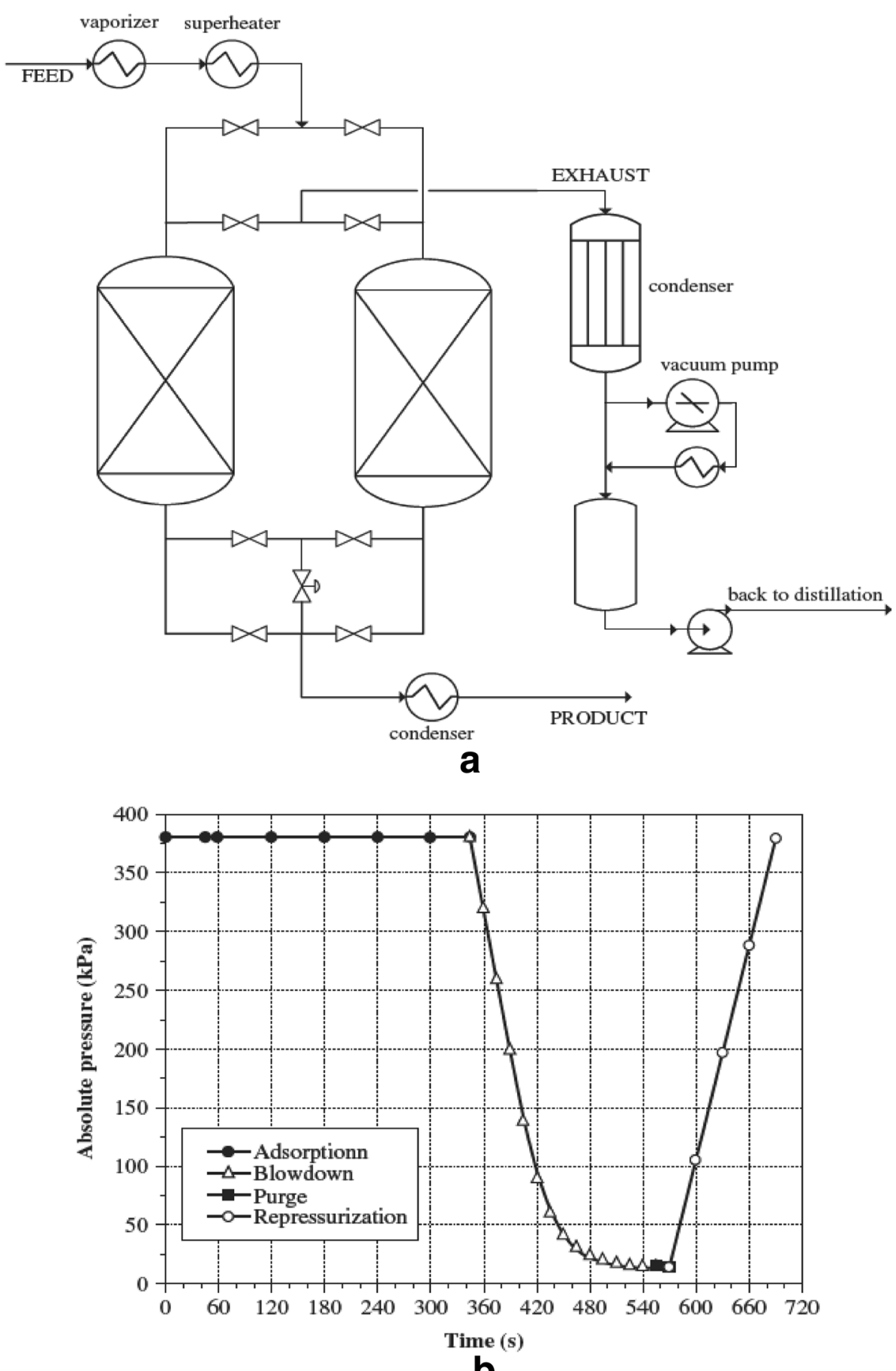

b

Fig. 1 Pressure swing adsorption: a two bed pressure swing adsorption process [Ref. (Simo 2013)] Copyrights John Wiley and Sons, 2013. Reprinted with permission from the publisher. b Pressure profile for two-bed ethanol PSA cycle [Ref. (Simo 2008)] Copyrights Elsevier, 2008. Reprinted with permission from the publisher 


\section{Agriculture byproducts-based biosorbents for purification of alcohols}

In literature, several biomaterials have been found to be effective adsorbents, such as-corn grits, potato starch, amylose, and maize starch (starch based) and wheat straw and woodchips (cellulose based). In the latter, xylans and hemicelluloses act as the major adsorbing components instead of amylopectin in case of former (Benson and George 2005). Based on the production of major crops in the world, rice straw, wheat straw, corn stover/straw, and sugarcane bagasse are the most generated agricultural residues. In USA alone, the total biomass potential would be about 680 million tons till 2030 which can be utilized for biofuel production and purification as biosorbents (Union of Concerned Scientists 2012). The typical composition and global availability of major agricultural residues have been presented in Table 4. In addition, Fig. 2 presents the typical structure of a lignocellulosic biomaterial comprising cellulose, hemicellulose, and lignin. Plant biomass is typically composed of three polymers: cellulose, hemicellulose, and lignin along with smaller amounts of protein, extractives, pectin, and ash. The composition of biomass can vary from one plant species to another (Bajpai 2016).

In general, biomaterials contain about $50-80 \%$ in the form of cellulose and hemicellulose which are important with respect to water adsorption on biomass. Lignin does not contribute much for water adsorption (Benson and George 2005). Common sources of biomass are: agricultural-food grain, bagasse (crushed sugarcane), corn stalks, straw, seed hulls, nutshells, poultry and hogs; forest-trees, wood waste, wood or bark, sawdust, timber slash and mill scrap; municipal-municipal solid waste, sewage sludge, refuse-derived fuel, food waste, waste paper and yard clippings; energy crops-poplars, willows, switch grass, corn, soybean, canola and other plant oils; and biological-animal wastes, aquatic species and biological wastes (Fantini 2017).

It was the pioneering efforts of Ladisch and Dyck in Purdue University that opened up a new era-the use of biological materials as adsorbents for drying of ethanol using cracked corn, starch, and cellulose (Ladisch and Dyck 1979). Since then, extensive research has been carried out using a wide range of biomaterials such as corn grits, corn meal, canola meal, corn cobs, and barley straw for removal of water from alcohol and gases (Anderson et al. 1996; Ladisch 1997; Chang et al. 2006; Ranjbar et al. 2013; Tajallipour et al. 2013; Jayaprakash et al. 2017; Dhabhai et al. 2018; Hong et al. 1982). The only biomaterial that was applied at an industrial scale is corn grits, which has been used since 1984 for drying methanol, ethanol, propanol, and tert-butanol vapors (Ladisch 1997; Beery et al. 1998). PSA has been used for this drying application (Beery and Ladisch 2001). Corn grits are used in industry to dry 2.8 billion liters of fuel-grade ethanol annually produced by fermentation, which is over half of the fuel-grade ethanol produced in the US (Beery et al. 1998). However, use of corn exerts pressure on food availability. Water adsorption with biomass-based adsorbents may consume less energy than adsorption using other adsorbents. Furthermore, biomass adsorbents require less energy for regeneration as well compared to synthetic adsorbents. Also, when regeneration is not possible, the spent biosorbent can be utilized for biofuel or bioenergy production (Rattanaphanee et al. 2013).

The generation, use, and disposal/reuse of biosorbents have been depicted in Fig. 3. The use of biomaterials as adsorbents is advantageous as compared to most commonly used chemical-based adsorbents-commercial molecular sieves. Biomaterials are derived from renewable biomass and are nontoxic and biodegradable (Baylak et al. 2012). In addition, the production of

Table 4 Typical composition and global availability of agricultural residues. Modified from Ref. (Tye et al. 2016; Canola council of Canada 2017)

\begin{tabular}{|c|c|c|c|c|}
\hline \multirow[t]{2}{*}{ Agricultural residues } & \multirow{2}{*}{$\begin{array}{l}\text { Non-wood fibers annual } \\
\text { production (million tons) }\end{array}$} & \multicolumn{3}{|c|}{ Chemical composition of non-wood lignocellulosic biomass } \\
\hline & & Cellulose (\%) & Hemicellulose (\%) & Lignin (\%) \\
\hline Barley straw & 51.3 & $33.3-42$ & $20.4-28.0$ & 17.1 \\
\hline Corn stover/straw & 376.8 & $35.0-42.6$ & $17.0-35.0$ & $7-21$ \\
\hline Oat straw & 10.4 & 37.6 & 23.34 & 12.85 \\
\hline Rice straw & 657.5 & $32.0-47.0$ & $18.0-28.0$ & $5.5-24.0$ \\
\hline Sorghum straw & 12.0 & 32.4 & 27.0 & 3.9 \\
\hline Wheat straw & 472.2 & $33.0-45.0$ & $20.0-32.0$ & $155.8-212.5$ \\
\hline Sugarcane bagasse & 1044.8 & 45.4 & 28.7 & 474.3 \\
\hline Oil palm biomass & 63.9 & $35.8-56.0$ & $21.9-44.0$ & $22.9-35.8$ \\
\hline Canola meal & 46.7 & 26.4 (cellulose + lignin) & 6.3 & \\
\hline
\end{tabular}




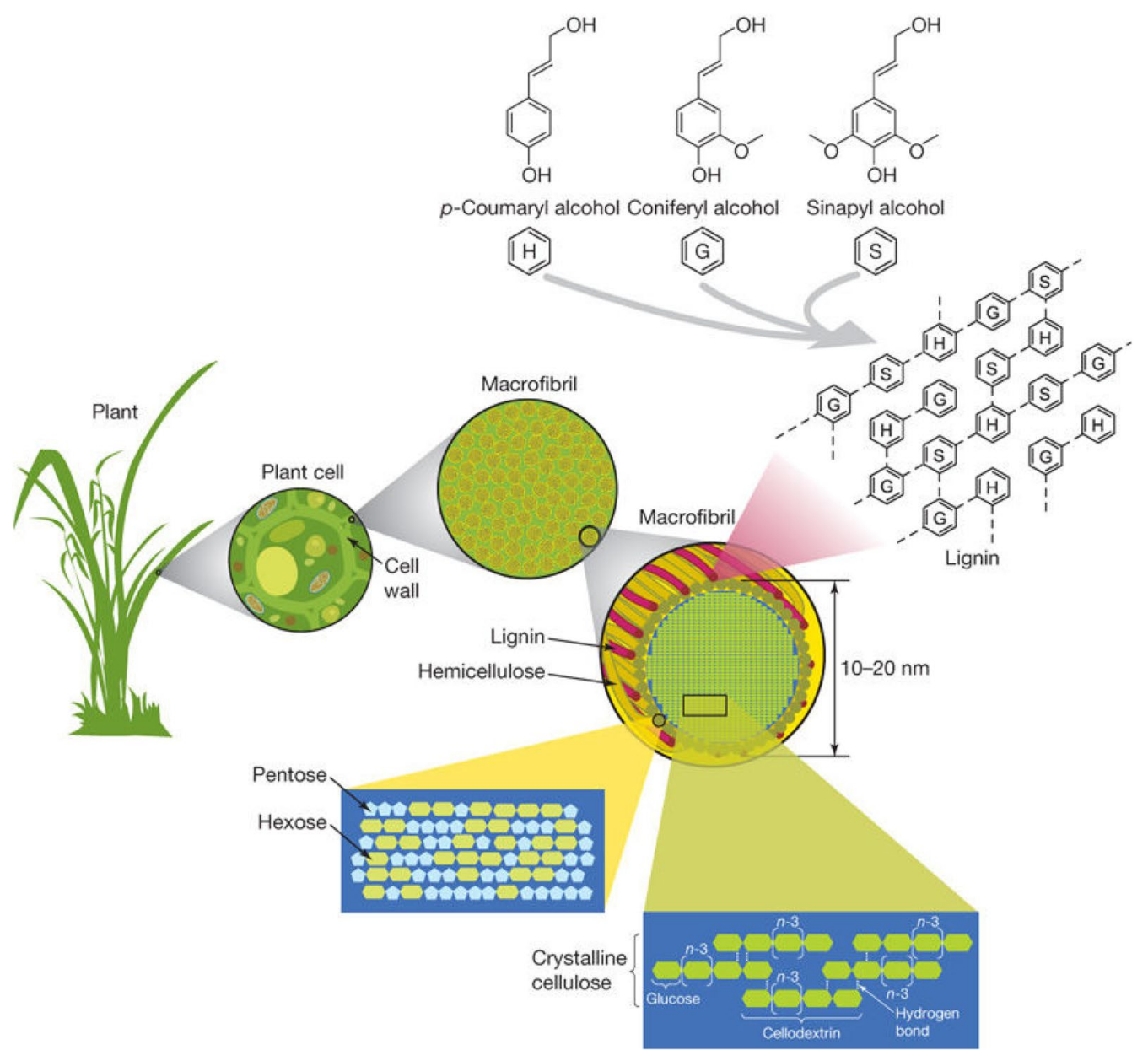

Fig. 2 Structure of lignocellulosic biosorbent depicting three major components of biomass —cellulose, hemicellulose, and lignin [Ref. (Rubin 2008)] (Copyrights Nature Publishing Group, 2008. Reprinted with permission from the publisher)

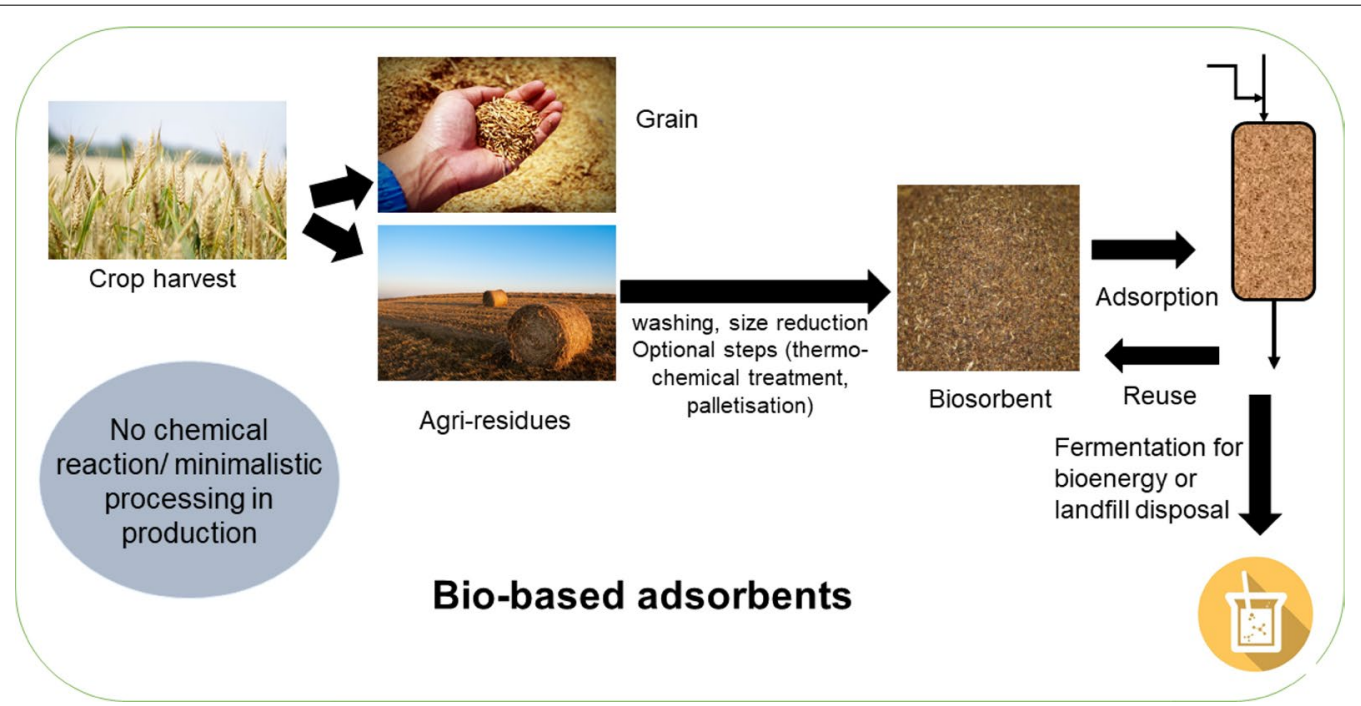

Fig. 3 Schematic of generation, use, and disposal of biosorbents 
biosorbents requires minimal processing and no chemical and thermal reactions like chemical adsorbents which often require high temperature activation. Moreover, the temperature of regeneration for biosorbents is much lower $\left(<110{ }^{\circ} \mathrm{C}\right)$ compared to commercial molecular sieves $\left(>190^{\circ} \mathrm{C}\right)$ (Ranjbar et al. 2013; Tajallipour et al. 2013; Jayaprakash et al. 2017). Even if regeneration is not possible with biosorbent, it can still be utilized as a raw material for the production of biofuels (Benson and George 2005). It is to be noted that activate carbon produced from renewable biomass has not been included in the present definition of biosorbents as activate carbon production requires elevated temperature/pressure conditions.

\section{Key features of biosorbents for purification of bioalcohols}

Many of the categories of biomass described above can be used as adsorbents for dehydration of alcohols. The most common is the agricultural and forest residues because of their large-scale production and availability, renewability, cost-effectiveness, and non-competitiveness with food. One of the most predominant features with respect to water adsorption is the available surface area and pore volume. The higher the surface area, the higher may be the adsorption capacity. However, for raw biomaterials, surface area is generally low (in the range of $2-50 \mathrm{~m}^{2} / \mathrm{g}$ ). The enhancement of surface characteristic such as increasing polar groups and surface area can be done by the treatment of biomass with mineral acids (Dhabhai et al. 2018; Yan and Niu 2017a), alkali (Imadi and Kazi 2015), or surface-active solvents or ionic liquids (Lee et al. 2009; Hou et al. 2012) which selectively remove components like volatile compounds, or lignin from the biomass. However, removal of biomass components may also be counterproductive as structural integrity of material is compromised. Jayaprakash et al. (2017) demonstrated that canola meal biosorbent has higher water adsorption capacity than the single substance of its main components such as cellulose and protein (Jayaprakash 2016).

Another key feature is the affinity with water molecules. One of the proposed mechanisms for adsorption is polar-polar interactions between adsorbent surface and adsorbate. Water adsorption by biomaterials is reported to involve the polar attraction between water and the cellulosic hydroxyl components and the protein carboxyl and amine groups in the adsorbent (Benson and George 2005; Jayaprakash et al. 2017; Dhabhai et al. 2018). Figure 4 a presents the structural features of common biomaterials depicted using FTIR (Fourier transform infrared) spectra. Biomaterials contain cellulose and hemicellulose, which have polar groups such as carboxyl, hydroxyl, and/or amino groups, and have the potential for selective water adsorption as the polarity of water is higher as compared to alcohols. Xylan from hemicellulose itself can separate water from ethanol, and cellulose also has sorptive properties (Ladisch 1997). These polar groups can bond with water through hydrogen bonding and van der wall interactions which are weaker and reversible in nature as compared to ionic interaction. On the biomass, available polar groups are the key. The higher the number of polar groups on the surface of biomass, the better the water retention by biomaterial. In addition, most biomaterials are stable up to $200{ }^{\circ} \mathrm{C}$ or more as depicted in Fig. $4 \mathrm{~b}$ in the thermogravimetric curves of representative biomaterials, they are suitable for being used in vapor phase adsorption at a temperature no higher than that range.

Another key feature for biosorbents for water adsorption is their pore size. As the size of water molecule is smaller $(0.28 \mathrm{~nm})$, as compared to ethanol $(0.44 \mathrm{~nm})$ and butanol $(0.51 \mathrm{~nm})$, it can penetrate more easily into the pores of the adsorbent (Dhabhai et al. 2018; Jayaprakash et al. 2017; Sun et al. 2007). In addition, the biomass particle size also affects the adsorption capability. Sun et al. (2007) compared three different biomaterials as adsorbent and found that higher water adsorption and selectivity were obtained with barley straw compared with wheat straw and crab shells. The smaller the particle size, the higher the surface area which may affect the adsorption rate of water or ethanol. Other operation parameters such as vapor flow rate, temperature, and water concentration have a large impact on performance of ethanol dehydration by starch-based adsorbents and cellulosebased adsorbents (Baylak et al. 2012).

\section{Preparation of biosorbents for alcohols dehydration}

Most cellulosic containing agricultural biomaterials can be used as a sorbent after initial washing and size reduction as described in Fig. 3. However, to improve the water adsorption capacity of adsorbents, thermochemical pretreatment may be a viable option for biosorbents, as it leads to increase in available surface area and pore volume, which may lead to enhancement of water adsorption capacity. There are a number of thermochemical treatment options for agricultural materials. Generally, as thermal treatment is an energy intensive process, it may add significantly to the cost of biosorbent preparation. Structural characteristics of lignocellulosic biomass such as surface area, pore volume, crystallinity, hemicellulose, and lignin content significantly affect the performance of biosorbents (Dhabhai et al. 2013). Generally, all pretreatment methods result in an increased surface area and pore volume as compared to untreated material. Increased porosity results from a combination of 


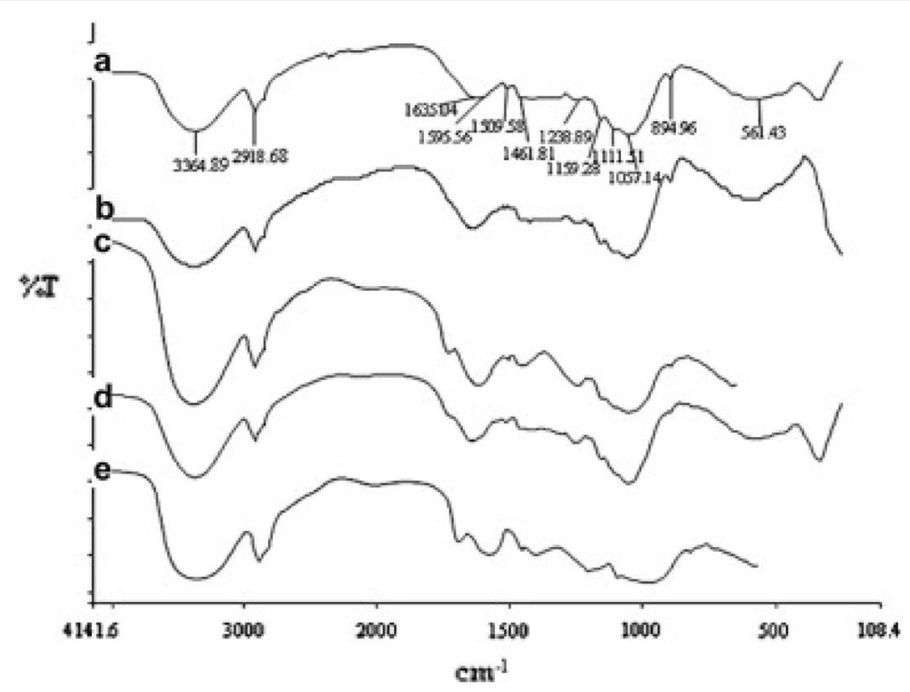

a

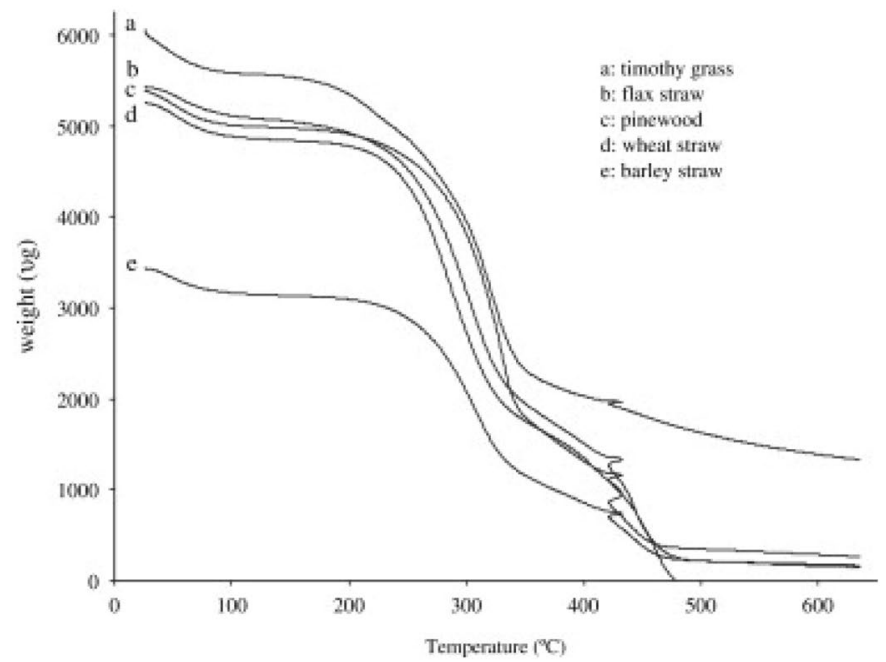

b

Fig. 4 Structural characterization of different biomaterials showing their key features. a FTIR spectra. b Thermogravimetric analysis [Ref. (Naik et al. 2010)] (Copyrights Elsevier, 2010. Reprinted with permission from the publisher)

hemicellulose solubilization, lignin solubilization, and lignin redistribution (Manzanares 2010).

One of the most commonly employed pretreatment methods is dilute acid pretreatment (sulfuric, hydrochloric, phosphoric, nitric or mixed acids in varying concentration) with or without high-pressure steam explosion. During this pretreatment, hemicellulose is readily hydrolyzed, while cellulose is minimally affected (Hendriks and Zeeman 2009; Alvira et al. 2010; Mood et al. 2013). Apart from acids, alkali (such as $\mathrm{NaOH}, \mathrm{KOH}, \mathrm{Ca}(\mathrm{OH})_{2}$ ) is also used for pretreatment which acts by the saponification of intermolecular ester bonds cross-linking xylan hemicelluloses and other components (Mood et al.
2013; Singh et al. 2014). Alkali pretreatment is more efficient in removing lignin but less effective in hemicellulose hydrolysis (Hendriks and Zeeman 2009; Alvira et al. 2010). In addition, organosolv, $\mathrm{CO}_{2}$ explosion, ammonia fiber expansion (AFEX), liquid hot water, wet oxidation, freezing or combination pretreatment have been applied to various cellulosic agricultural materials (Alvira et al. 2010; Mood et al. 2013). 


\section{Adsorption systems for bioalcohols dehydration using biosorbents}

\section{Liquid phase adsorptive dehydration}

Most commonly, the liquid is a homogenous (in case of water-ethanol mixture) or heterogeneous binary mixture (in case of water-butanol mixture) after the initial purification steps such as filtration and distillation in the respective industrial processes through fermentation. The mixture of water and ethanol is a homogenous and completely miscible solution. In case of an heterogeneous mixture of water and butanol, as butanol is partially miscible in water [at $25^{\circ} \mathrm{C}$, solubility of butanol in water is $7.4 \mathrm{wt} \%$ and that of water in butanol is 20.3 wt\% (Kertes 1984)], vigorous mixing may be required to keep the mixture 'pseudo-homogenous' for adsorption to occur (Dhabhai et al. 2018). The advantages of liquid phase adsorption include-(1) less energy requirement as the sorption can be carried out at room temperature and ambient pressure; (2) simplicity of operation, as it can be carried out in a stirred tank or packed column; (3) a large number of adsorbents can be screened quickly to test their adsorption capacities. On the other hand, as the liquid directly interacts with the adsorbent surface, it may lead to leaching of biomass components into the liquid mixture, which is undesirable for final product purity and appearance. Table 5 presents the summary of the recent literature on liquid phase drying of ethanol and butanol.

Most of the work has been done for ethanol dehydration while only a handful of studies are for water removal from butanol aqueous solutions in liquid phase. Barley straw, miscanthus, and canola meal biosorbents both in their raw and treated form have shown higher water adsorption capacities (0.2$0.6 \mathrm{~mol} / \mathrm{g}$ ) than commercial molecular sieves. However, because raw biomass tended to degrade in liquid solution, currently they are more applicable for drying application in vapor/gas phase. Further enhancement of biosorbents by reducing release of compounds of biomass into liquid phase is necessary in order for industrial adsorption application in liquid phase.

This can possibly be achieved by (a) water washing the biomass and air drying before adsorption; (b) alcohol extraction for a brief period without affecting biomaterial structural features; (c) thermochemical

Table 5 Biobased sorbents for liquid phase drying of ethanol and butanol

\begin{tabular}{|c|c|c|c|c|c|c|}
\hline $\begin{array}{l}\text { Adsorbent- } \\
\text { adsorbate }\end{array}$ & $\begin{array}{l}\text { Adsorbent } \\
\text { surface area } \\
\left(\mathrm{m}^{2} / \mathrm{g}\right)\end{array}$ & $\begin{array}{l}\text { Reaction } \\
\text { conditions/system }\end{array}$ & $\begin{array}{l}\text { Water } \\
\text { adsorption } \\
\text { capacity }(\mathrm{mol} / \mathrm{g})\end{array}$ & Separation factor & $\begin{array}{l}\text { Initial and final } \\
\text { alcohol } \\
\text { concentration (\%) }\end{array}$ & Refs. \\
\hline Barley straw/ethanol & 1.08 & $\begin{array}{l}\text { Room temperature, } \\
130 \text { rpm, } 4 \mathrm{~g} \text { in } \\
150 \mathrm{ml} \mathrm{liquid}\end{array}$ & 0.43 & 6.15 & 5-90 to pure & Sun et al. (2007) \\
\hline Wheat straw/ethanol & 0.73 & $\begin{array}{l}\text { Room temperature, } \\
130 \text { rpm, } 4 \mathrm{~g} \text { in } \\
150 \mathrm{ml} \mathrm{liquid}\end{array}$ & 0.22 & 6 & 5-90 to pure & Sun et al. (2007) \\
\hline $\begin{array}{c}\text { Crab shells of Ucides } \\
\text { cordatus/ethanol }\end{array}$ & NA & $\begin{array}{l}\text { Room temperature, } \\
130 \text { rpm, } 4 \mathrm{~g} \text { in } \\
150 \mathrm{ml} \text { liquid }\end{array}$ & 0.02 & 4.5 & 5-90 to pure & Sun et al. (2007) \\
\hline $\begin{array}{l}\text { Barley straw (raw- } \\
\text { untreated)/ethanol }\end{array}$ & $2 \mathrm{~m}^{2} / \mathrm{g}$ & Room temp.; 150 rpm & 0.50 & & 78 to 83 & Yan and Niu (2017b) \\
\hline $\begin{array}{l}\text { Barley straw (pre- } \\
\text { treated using } \mathrm{H}_{3} \mathrm{PO}_{4} \\
\text { in microwave)/ } \\
\text { ethanol }\end{array}$ & $105-1314 \mathrm{~m}^{2} / \mathrm{g}$ & Room temp.; 150 rpm & 0.63 & & 78 to 89 & Yan and Niu (2017b) \\
\hline $\begin{array}{l}\text { Miscanthus (raw)/ } \\
\text { ethanol }\end{array}$ & $0.43-0.74$ & $\begin{array}{l}\text { Room temperature; } \\
24 \text { h at } 160 \text { rpm. }\end{array}$ & $0.21-0.50$ & $1.5-3.0$ & & Dhabhai et al. (2017) \\
\hline $\begin{array}{l}\text { Miscanthus (pre- } \\
\text { treated)/ethanol }\end{array}$ & $0.71-0.96$ & $\begin{array}{l}\text { Room temperature; } \\
24 \mathrm{~h} \text { at } 160 \mathrm{rpm}\end{array}$ & $0.16-0.26$ & & & Dhabhai et al. (2017) \\
\hline Canola meal/ethanol & NA & $\begin{array}{l}\text { Room temperature, } \\
130 \text { rpm, } 4 \mathrm{~g} \text { in } \\
150 \mathrm{ml} \mathrm{liquid}\end{array}$ & 0.13 & $2.5-4.0$ & 4-90 to pure & Ranjbar et al. (2013) \\
\hline $\begin{array}{l}\text { Canola meal (raw; } \\
\text { untreated)/butanol }\end{array}$ & 13.2 & $\begin{array}{l}\text { Room tempera- } \\
\text { ture; } 150 \mathrm{rpm} ; \\
0.43-1.18 \mathrm{~mm} \\
\text { particle size }\end{array}$ & $0.24-0.31$ & & $5-90$ to $19.8-96$ & Dhabhai et al. (2017) \\
\hline $\begin{array}{l}\text { Canola meal } \\
\text { (pretreated; using } \\
\mathrm{H}_{2} \mathrm{SO}_{4} \text { in a micro- } \\
\text { wave)/butanol }\end{array}$ & 147.5 & $\begin{array}{c}\text { Room temperature; } \\
0.43-1.18 \mathrm{~mm} \text { par- } \\
\text { ticle size; } 150 \text { rpm }\end{array}$ & $0.11-0.13$ & & 5-90 to 23-98 & Dhabhai et al. (2018) \\
\hline
\end{tabular}


Table 6 Biobased sorbents for vapor phase drying of ethanol, butanol, and other alcohols

\begin{tabular}{|c|c|c|c|c|c|c|}
\hline $\begin{array}{l}\text { Adsorbent- } \\
\text { adsorbate }\end{array}$ & $\begin{array}{l}\text { Adsorbent } \\
\text { surface area } \\
\left(\mathrm{m}^{2} / \mathrm{g}\right)\end{array}$ & $\begin{array}{l}\text { Reaction conditions/ } \\
\text { system }\end{array}$ & $\begin{array}{l}\text { Water adsorption } \\
\text { capacity }\end{array}$ & $\begin{array}{l}\text { Separation } \\
\text { factor }\end{array}$ & $\begin{array}{l}\text { Initial and final } \\
\text { alcohol } \\
\text { concentration (\%) }\end{array}$ & Refs. \\
\hline $\begin{array}{l}\text { Bleached wood } \\
\text { pulp/ethanol }\end{array}$ & NA & Vapor phase & $0.386 \mathrm{~g} / \mathrm{g}$ & & $90-97$ to 99.5 & $\begin{array}{l}\text { Benson and George } \\
\text { (2005) }\end{array}$ \\
\hline $\begin{array}{l}\text { Oak sawdust/etha- } \\
\text { nol }\end{array}$ & NA & Vapor phase & $0.285 \mathrm{~g} / \mathrm{g}$ & - & $90-97$ to 99.5 & $\begin{array}{l}\text { Benson and George } \\
\text { (2005) }\end{array}$ \\
\hline Kenaf core/ethanol & NA & Vapor phase & $0.200 \mathrm{~g} / \mathrm{g}$ & - & $90-97$ to 99.5 & $\begin{array}{l}\text { Benson and George } \\
\text { (2005) }\end{array}$ \\
\hline $\begin{array}{l}\text { ZSG-1 (startch } \\
\text { based)/ethanol }\end{array}$ & NA & Vapor phase; $81-89^{\circ} \mathrm{C}$ & $0.20-0.23 \mathrm{~g} / \mathrm{g}$ & & 90 to 99.7 & Wang et al. (2010) \\
\hline Cassava/ethanol & NA & $\begin{array}{l}\text { Vapor phase, } 60 \mathrm{~g} \text { adsorbent } \\
\text { for } 500 \mathrm{ml} \text { alcohol vapor }\end{array}$ & $0.053 \mathrm{~g} / \mathrm{g}$ & & 80 to 98.1 & $\begin{array}{l}\text { Rattanaphanee et al. } \\
\text { (2013) }\end{array}$ \\
\hline Wheat flour/ethanol & NA & Vapor phase; $50-90^{\circ} \mathrm{C}$ & & $\sim 500$ & - & Vareli et al. (2000) \\
\hline $\begin{array}{l}\text { Wheat straw/etha- } \\
\text { nol }\end{array}$ & NA & Vapor phase; $50-90^{\circ} \mathrm{C}$ & & $\sim 650$ & & Vareli et al. (2000) \\
\hline Corn starch/ethanol & $0.82-0.98 \mathrm{~m}^{2} / \mathrm{g}$ & Vapor phase; $90^{\circ} \mathrm{C}$ & $0.098-0.19 \mathrm{~g} / \mathrm{g}$ & & 92 to $95-99$ & $\begin{array}{l}\text { Qintero and Car- } \\
\text { dona (2009) }\end{array}$ \\
\hline $\begin{array}{l}\text { Upright elephant } \\
\text { ear/ethanol }\end{array}$ & $2.17-2.87 \mathrm{~m}^{2} / \mathrm{g}$ & Vapor phase; $90^{\circ} \mathrm{C}$ & $0.04-0.06 \mathrm{~g} / \mathrm{g}$ & & 92 to 98.72 & $\begin{array}{l}\text { Qintero and Car- } \\
\text { dona (2009) }\end{array}$ \\
\hline Cassava/ethanol & $0.50-0.66 \mathrm{~m}^{2} / \mathrm{g}$ & Vapor phase; $90^{\circ} \mathrm{C}$ & $0.06-0.08 \mathrm{~g} / \mathrm{g}$ & & 92 to $97.4-99.4$ & $\begin{array}{l}\text { Qintero and Car- } \\
\text { dona (2009) }\end{array}$ \\
\hline $\begin{array}{l}\text { Canola meal/etha- } \\
\text { nol }\end{array}$ & NA & $\begin{array}{l}\text { Vapor phase; } 85^{\circ} \mathrm{C}, 216 \mathrm{kPa} \text {; } \\
\quad 0.43-1.18 \mathrm{~mm}\end{array}$ & $0.013-0.025 \mathrm{~g} / \mathrm{g}$ & $1.6-1.8$ & $75-92$ to $>99$ & Baylak et al. (2012) \\
\hline Corn meal/ethanol & $153.55 \mathrm{~m}^{2} / \mathrm{g}$ & Vapor phase; $82-100{ }^{\circ} \mathrm{C}$ & $0.0135-0.20 \mathrm{~g} / \mathrm{g}$ & $8.88-33.85$ & & Chang et al. (2006) \\
\hline Corn meal/ethanol & NA & Vapor phase; $82-100^{\circ} \mathrm{C}$ & $0.01-0.068 \mathrm{~g} / \mathrm{g}$ & $8.88-22.79$ & 85 to 93.8 & Chang et al. (2006) \\
\hline Corn meal/ethanol & NA & $\begin{array}{l}\text { Vapor phase; } 87^{\circ} \mathrm{C} \text { and par- } \\
\text { ticle size of } 60-100 \text { mesh }\end{array}$ & $0.014-0.025 \mathrm{~g} / \mathrm{g}$ & & 95 to 99.5 & (Hu and Xie 2001) \\
\hline Palm stone/ethanol & $350-400 \mathrm{~m}^{2} / \mathrm{g}$ & Vapor phase & $0.125 \mathrm{~g} / \mathrm{g}$ & & & Al-Asheh et al. (2004) \\
\hline $\begin{array}{l}\text { Canola meal/etha- } \\
\text { nol }\end{array}$ & NA & $\begin{array}{l}\text { Vapor phase; } 90-110^{\circ} \mathrm{C} \text { and } \\
136-243 \mathrm{kPa} \text {. }\end{array}$ & $0.01-0.08$ & $2.37-2.78$ & $80-95$ to $>99 \%$ & Ranjbar et al. (2013) \\
\hline $\begin{array}{l}\text { Canola meal/ } \\
\text { butanol }\end{array}$ & NA & $\begin{array}{l}\text { Vapor phase; } 95-111^{\circ} \mathrm{C} ; \\
135-201 \mathrm{kPa} \text {; flow rate } \\
1.5-3 \mathrm{ml} / \mathrm{min}\end{array}$ & $0.02-0.64 \mathrm{~g} / \mathrm{g}$ & $0.40-3.22$ & $\sim 55$ to $>99$ & $\begin{array}{l}\text { Jayaprakash et al. } \\
\text { (2017) }\end{array}$ \\
\hline $\begin{array}{l}\text { ZSG-1 (startch } \\
\text { based)/isopro- } \\
\text { panol }\end{array}$ & $127 \mathrm{~m}^{2} / \mathrm{g}$ & Vapor phase; $88-92^{\circ} \mathrm{C}$ & & 545 & 90-98 to pure & Wu et al. (2015) \\
\hline Cassava/isopropanol & NA & $\begin{array}{l}\text { Vapor phase, } 60 \mathrm{~g} \text { adsorbent } \\
\text { for } 500 \mathrm{ml} \text { alcohol vapor }\end{array}$ & $0.119 \mathrm{~g} / \mathrm{g}$ & & $80-98.1$ & $\begin{array}{l}\text { Rattanaphanee et al. } \\
\text { (2013) }\end{array}$ \\
\hline Cassava/n-propanol & NA & $\begin{array}{l}\text { Vapor phase, } 60 \mathrm{~g} \text { adsorbent } \\
\text { for } 500 \mathrm{ml} \text { alcohol vapor }\end{array}$ & $0.109 \mathrm{~g} / \mathrm{g}$ & & 65 to 86.2 & $\begin{array}{l}\text { Rattanaphanee et al. } \\
\text { (2013) }\end{array}$ \\
\hline
\end{tabular}

treatment employing dilute acid or alkali; (d) immobilisation of biomaterial preventing leaching of biomass components but allowing water adsorption.

\section{Vapor phase adsorptive dehydration}

In the literature, several biosorbents have been successfully employed for bioalcohols dehydration by vapor phase adsorption. The biggest advantage of vapor phase adsorption is that the process can be continuous and the biosorbent can be reused several times without deterioration as the liquid is not in direct contact with the adsorbents (Chang et al. 2006; Ranjbar et al. 2013; Tajallipour et al. 2013; Jayaprakash et al. 2017).

Table 6 presents the compilation of literature for use of biosorbents in vapor phase adsorption. Ethanol dehydration on canola meal was investigated in a fixed-bed system; 99 wt\% fuel grade ethanol was achieved from 75 and $92 \mathrm{wt} \%$ ethanol-water mixtures using canola meal as biosorbents (Baylak et al. 2012). Benson and George (2005) did a comparison of three different biomaterials. The bleached wood pulp demonstrated the highest water loading followed by kenaf core and then oak sawdust. Wang et al. (2010) developed a new starch-based 
adsorbent for separation of ethanol/water azeotrope named ZSG-1 which yielded $99.7 \%$ anhydrous ethanol with high efficiency (as high as molecular sieves). ZSG-1 consisted of corn, sweet potato and a foaming agent. Recently, Wu et al. (2015) characterized and tested the efficiency of this same adsorbent for breaking the azeotrope of isopropanol and water $(87.4-87.7 \%$ by weight). Molecular sieves of type 3A, type $4 \mathrm{~A}$, and type $5 \mathrm{~A}$ and biobased adsorbents such as natural corncobs, natural and activated palm stone and oak were used in a study. The performances of the adsorbents examined in this work for ethanol drying have the following order: type $3 \mathrm{~A}>$ type $4 \mathrm{~A}>$ natural palm stone $>$ natural corncobs $>$ activated palm stone $>$ natural oak $>$ type $5 \mathrm{~A}>$ activated oak (Al-Asheh et al. 2004). Vareli et al. (2000) studied the effect of regeneration temperature on ethanol dehydration using starch containing (wheat flour) and cellulosic (wheat straw) adsorbents. The adsorption and regeneration temperatures were $50-90$ and $140-170{ }^{\circ} \mathrm{C}$, respectively, for $24 \mathrm{~h}$. The higher regeneration temperature affected water adsorption whereas it showed no effect on ethanol adsorption.

\section{Conclusions}

Bioethanol and biobutanol are superior fuel additives. Bioalcohols require extensive purification after their fermentative production as current fuel alcohol standards require $>99 \%$ purity. Adsorption is one of the most efficient and cost-effective technologies for dehydration of bioalcohols. Based on their low cost of production and widespread availability, biobased materials which contain cellulose, hemicellulose, proteins, and lignin as their constituents have an excellent potential to be used industrially for dehydration of alcohols in vapor phase. Pressure swing adsorption is the choice of method industrially because of the ease of operation and maintenance and cost-effectiveness. The cellulose and hemicellulose content of biosorbents can be in the range of $50-80 \%$ and they primarily possess polar groups such as hydroxyl, carboxyl, and amine which help in water adsorption by polar-polar interactions. The pore size, low crystallinity, and thermal properties are also helpful characteristics for higher water adsorption. The low cost and water adsorption efficiency validate their industrial candidacy for alcohols dehydration. Future work is required to improve the properties of biosorbents for adsorption application in liquid phase.

\section{Abbreviations}

ABE: acetone-butanol-ethanol (ABE); BTU: British thermal unit; FTIR: Fourier transform infrared; MTZ: mass transfer zone; PSA: pressure swing adsorption.

\section{Symbols}

$C$ : concentration of water at equilibrium $\left(\mathrm{g} \mathrm{g}^{-1}\right.$, also expressed as $\left.\mathrm{mol} \mathrm{g}^{-1}\right) ; C_{0}$ : initial concentration of water $\left(\mathrm{g} \mathrm{g}^{-1}\right.$, also expressed as $\left.\mathrm{mol} \mathrm{g}^{-1}\right)$.

\section{Authors' contributions}

$\mathrm{RD}$ who was a postdoctoral research fellow wrote the manuscript. CN was the principal supervisor and AD was the co-supervisor to supervise RD to complete the research project. CN and AD also provided comments and/or revisions to the manuscript. All authors read and approved the final manuscript.

\begin{abstract}
Acknowledgements
The authors would like to give thanks to all funding support. We also very much appreciate the feedback and advices of R. Tyagi, Chief Executive Officer of the Spectrum Technologies Ltd. in Canada, to this research project.
\end{abstract}

\section{Competing interests}

The authors declare that they have no competing interests.

\section{Availability of data and materials}

This is a review paper. The data supporting the conclusions of this paper are presented in the form of text, graph or table in this paper. The authors have agreed to provide additional data or materials associated with this paper upon request.

Consent for publication

Not applicable.

Ethics approval and consent to participate Not applicable.

\section{Funding}

Financial support for this project was provided by MITACS (IT04850), Natural Science and Engineering Research Council of Canada (No. RGPIN 2990612013), Canada Foundation for Innovation (No. 33172), Saskatchewan Ministry of Agriculture and the Canada-Saskatchewan Growing Forward 2-bilateral agreement (No. 20130220), Saskatchewan Canola Development Commission (No. 20130220), and Western Grains Research foundation (No. 20130220).

\section{Publisher's Note}

Springer Nature remains neutral with regard to jurisdictional claims in published maps and institutional affiliations.

Received: 14 March 2018 Accepted: 23 July 2018

Published online: 04 August 2018

\footnotetext{
References

Abdehagh N, Tezel FH, Thibault J (2013) Adsorbent screening for biobutanol separation by adsorption: kinetics, isotherms and competitive effect of other compounds. Adsorption 19:1263-1272. https://doi.org/10.1007/ s10450-013-9566-8

Abdehagh N, Tezel FH, Thibault J (2014) Separation techniques in butanol production: challenges and developments. Biomass Bioenerg 60:222-246. https://doi.org/10.1016/j.biombioe.2013.10.003

Abdehagh N, Tezel FH, Thibault J (2016) Multicomponent adsorption modeling: isotherms for ABE model solutions using activated carbon F-400. Adsorption 22:357-370. https://doi.org/10.1007/s10450-016-9784-y

Abdehagh N, Dai B, Thibault J, Handan Tezel F (2017) Biobutanol separation from $A B E$ model solutions and fermentation broths using a combined adsorption-gas stripping process. J Chem Technol Biotechnol 92:245251. https://doi.org/10.1002/jctb.4977

Al-Asheh S, Banat F, Al-Lagtah N (2004) Separation of ethanol-water mixtures using molecular sieves and biobased adsorbents. Chem Eng Res Des 82:855-864. https://doi.org/10.1205/0263876041596779

Alvira P, Tomás-Pejó E, Ballesteros M, Negro MJ (2010) Pretreatment technologies for an efficient bioethanol production process based on enzymatic
} 
hydrolysis: a review. Bioresour Technol 101:4851-4861. https://doi. org/10.1016/j.biortech.2009.11.093

Anderson LE, Gulati M, Westgate PJ et al (1996) Synthesis and optimization of a new starch-based adsorbent for dehumidification of air in a pressureswing dryer. Ind Eng Chem Res 35:1 180-1187. https://doi.org/10.1021/ ie9504213

Bajpai P (2016) Structure of lignocellulosic biomass. Pretreatment of lignocellulosic biomass for biofuel production. Springer, Singapore, pp 7-12

Balat M (2011) Production of bioethanol from lignocellulosic materials via the biochemical pathway: a review. Energy Convers Manag 52:858-875. https ://doi.org/10.1016/j.enconman.2010.08.013

Baylak T, Kumar P, Niu CH, Dalai A (2012) Ethanol dehydration in a fixed bed using canola meal. Energy Fuels 26:5226-5231. https://doi.org/10.1021/ ef300118s

Beery KE, Ladisch MR (2001) Adsorption of water from liquid-phase ethanolwater mixtures at room temperature using starch-based adsorbents. Ind Eng Chem Res 40:2112-2115. https://doi.org/10.1021/ie0009381

Beery KE, Gulati M, Kvam EP, Ladisch MR (1998) Effect of enzyme modification of corn grits on their properties as an adsorbent in a Skarstrom pressure swing cycle dryer. Adsorption 4:321-335. https://doi. org/10.1023/A:1008846003116

Bello RH, Linzmeyer P, Franco CMB et al (2014) Pervaporation of ethanol produced from banana waste. Waste Manag 34:1501-1509. https://doi. org/10.1016/j.wasman.2014.04.013

Benson TJ, George CE (2005) Cellulose based adsorbent materials for the dehydration of ethanol using thermal swing adsorption. Adsorption 11:697-701. https://doi.org/10.1007/s10450-005-6009-1

Bharathi KS, Ramesh ST (2013) Removal of dyes using agricultural waste as low-cost adsorbents: a review. Appl Water Sci 3:773-790. https://doi. org/10.1007/s13201-013-0117-y

Canola Council of Canada (2017) Economic Impact of the Canola Industry. In: Canada Counc. Canada. http://www.canolacouncil.org/markets-stats/ industry-overview/economic-impact-of-the-canola-industry/

Chang H, Yuan X-G, Tian H, Zeng A-W (2006) Experimental investigation and modeling of adsorption of water and ethanol on cornmeal in an ethanol-water binary vapor system. Chem Eng Technol 29:454-461. https:// doi.org/10.1002/ceat.200500384

Costenoble O (2017) Worldwide Fuels Standards. Overview of specifications and regulations on (bio)fuels. In: NEN - Netherlands Standardization Institute

Crini G (2006) Non-conventional low-cost adsorbents for dye removal: a review. Bioresour Technol 97:1061-1085. https://doi.org/10.1016/j.biort ech.2005.05.001

Dhabhai R, Chaurasia SP, Dalai AK (2013) Effect of pretreatment conditions on structural characteristics of wheat straw. Chem Eng Commun 200(9):1251-1259. https://doi.org/10.1080/00986445.2012.743895

Dhabhai R, Niu CH, Dalai AK (2018) Selective adsorption of water from aqueous butanol solution using canola-meal-based biosorbents. Chem Eng Commun 205:637-646. https://doi.org/10.1080/00986445.2017.1412307

Fantini M (2017) Biomass availability, potential and characteristics. In: Rabaçal $M$, Ferreira AF, Silva CAM, Costa M (eds) Biorefineries: targeting energy, high value products and waste valorisation. Springer International Publishing, Cham, pp 21-54

Farzaneh A, DeJaco RF, Ohlin L et al (2017) Comparative study of the effect of defects on selective adsorption of butanol from butanol/water binary vapor mixtures in silicalite-1 films. Langmuir 33:8420-8427. https://doi. org/10.1021/acs.langmuir.7b02097

Fei C, Hongzhang C (2009) Absorption of ethanol by steam-exploded corn stalk. Bioresour Technol 100:1315-1318. https://doi.org/10.1016/j.biort ech.2008.08.009

Gupta VK, Suhas (2009) Application of low-cost adsorbents for dye removal-a review. J Environ Manag 90:2313-2342. https://doi.org/10.1016/j.jenvm an.2008.11.017

Hendriks ATWM, Zeeman G (2009) Pretreatments to enhance the digestibility of lignocellulosic biomass. Bioresour Technol 100:10-18. https://doi. org/10.1016/j.biortech.2008.05.027

Hong J, Voloch M, Ladisch MR, Tsao GT (1982) Adsorption of ethanol-water mixtures by biomass materials. Biotechnol Bioeng 24:725-730. https:// doi.org/10.1002/bit.260240314

Hou X-D, Smith TJ, Li N, Zong M-H (2012) Novel renewable ionic liquids as highly effective solvents for pretreatment of rice straw biomass by selective removal of lignin. Biotechnol Bioeng 109:2484-2493. https://doi. org/10.1002/bit.24522

Hu X, Xie W (2001) Fixed-bed adsorption and fluidized-bed regeneration for breaking the azeotrope of ethanol and water. Sep Sci Technol 36:125136. https://doi.org/10.1081/SS-100000856

Huang H-J, Ramaswamy S, Liu Y (2014) Separation and purification of biobutanol during bioconversion of biomass. Sep Purif Technol 132:513-540. https://doi.org/10.1016/j.seppur.2014.06.013

Imadi SR, Kazi AG (2015) Extraction of lignin from biomass for biofuel production. In: Hakeem KR, Jawaid M, Alothman OY (eds) Agricultural biomass based potential materials. Springer International Publishing, Cham, pp 391-402

Isaac A, Barboza V, Sket FI, D'Almeida JRM, Montoro LA, Hilger A, Manke I (2015) Towards a deeper understanding of structural biomass recalcitrance using phase-contrast tomography. Biotechnol Biofuels 8:40. https://doi. org/10.1186/s13068-015-0229-8

Jayaprakash D (2016) Drying butanol using biosorbents in a pressure swing adsorption process. University of Saskatchewan, SK, Canada

Jayaprakash D, Dhabhai R, Niu CH, Dalai AK (2017) Selective water removal by sorption from butanol-water vapor mixtures: analyses of key operating parameters and site energy distribution. Energy Fuels 31(5):5193-5202. https://doi.org/10.1021/acs.energyfuels.7b00310

Jeong J, Jeon H, Ko K et al (2012) Production of anhydrous ethanol using various PSA (pressure swing adsorption) processes in pilot plant. Renew Energy 42:41-45. https://doi.org/10.1016/j.renene.2011.09.027

Kertes KS (1984) Solubility data series, Alcohols with water. In: Anal. Chem. Div. Comm. solubility data, Int. union pure Appl. Chem

Kidnay J, Parrish WR, McCartney DG (2011) Fundamentals of natural gas processing. CRC Press, Boca Raton. ISBN-13:978-0-8493-3406-1

Kiss AA, Lange J-P, Schuur B (2016) Separation technology_Making a difference in biorefineries. Biomass Bioenerg 95:296-309. https://doi. org/10.1016/j.biombioe.2016.05.021

Kumar KV, de Castro MM, Martinez-Escandell M, Molina-Sabio M, RodriguezReinoso F (2011) A site energy distribution function from Toth isotherm for adsorption of gases on heterogeneous surfaces. Phys Chem Chem Phys 13:5753-5759

Ladisch MR (1997) Biobased adsorbents for drying of gases. Enzyme Microb Technol 20:160-164

Ladisch MR, Dyck K (1979) Dehydration of ethanol: new approach gives positive energy balance. Science (80-) 205:898-900. https://doi.org/10.1126/ science.205.4409.898

Lee SH, Doherty TV, Linhardt RJ, Dordick JS (2009) lonic liquid-mediated selective extraction of lignin from wood leading to enhanced enzymatic cellulose hydrolysis. Biotechnol Bioeng 102:1368-1376. https://doi. org/10.1002/bit.22179

Lemos DA, Sonego JLS, Boschiero MV et al (2017) Selection and application of nontoxic solvents in extractive ethanol fermentation. Biochem Eng J 127:128-135. https://doi.org/10.1016/j.bej.2017.08.003

Malik PK (2003) Use of activated carbons prepared from sawdust and rice-husk for adsorption of acid dyes: a case study of Acid Yellow 36. Dye Pigment 56:239-249. https://doi.org/10.1016/S0143-7208(02)00159-6

Manzanares P (2010) Bioalcohol production. Woodhead Publishing Limited, Cambridge

Mood SH, Golfeshan AH, Tabatabaei M et al (2013) Lignocellulosic biomass to bioethanol, a comprehensive review with a focus on pretreatment. Renew Sustain Energy Rev 27:77-93. https://doi.org/10.1016/j. rser.2013.06.033

Naik SN, Goud VV, Rout PK, Dalai AK (2010) Production of first and second generation biofuels: a comprehensive review. Renew Sustain Energy Rev 14:578-597. https://doi.org/10.1016/j.rser.2009.10.003

Niu CH, Baylak T, Wilson DI, Zhang M (2014) Pelletisation of canola meal by extrusion-spheronisation for ethanol dehydration. Biomass Bioenerg 66:116-125. https://doi.org/10.1016/j.biombioe.2014.03.035

Pal A, Kil HS, Mitra S et al (2017) Ethanol adsorption uptake and kinetics onto waste palm trunk and mangrove based activated carbons. Appl Therm Eng 122:389-397. https://doi.org/10.1016/.applthermaleng.2017.04.099

Perry RH(1997) Perry's chemical engineers' handbook, 7th edn. McGraw Hill Publication, USA. ISBN 0-07-115448-5

Prakash A, Dhabhai R, Sharma V (2016) A review on fermentative production of biobutanol from biomass. Curr Biochem Eng 3:37-46 
Pruksathorn P, Vitidsant T (2009) Production of pure ethanol from azeotropic solution by pressure swing adsorption. Korean J Chem Eng 26:11061111. https://doi.org/10.1007/s11814-009-0184-9

Qintero JA, Cardona CA (2009) Ethanol dehydration by adsorption with starchy and cellulosic materials. Ind Eng Chem Res 48:6783-6788. https://doi. org/10.1021/ie8015736

Qiu H, Lv L, Pan B et al (2009) Critical review in adsorption kinetic models. J Zhejiang Univ Sci A 10:716-724. https://doi.org/10.1631/jzus.A0820524

Raganati F, Procentese A, Olivieri G et al (2018) Bio-butanol separation by adsorption on various materials: assessment of isotherms and effects of other ABE-fermentation compounds. Sep Purif Technol 191:328-339. https://doi.org/10.1016/j.seppur.2017.09.059

Ranjbar Z, Tajallipour M, Niu CH, Dalai AK (2013) Water removal from ethanol vapor by adsorption on canola meal after protein extraction. Ind Eng Chem Res 52:14429-14440. https://doi.org/10.1021/ie4002662

Rattanaphanee P, Laha W, Boonfung C (2013) Desiccant from cassava for dehydration of alcohol vapor at near azeotropic concentration. In: Tan J (ed) Engineering materials and application, vol 651. Trans Tech Publications, pp 126-130

Rubin EM (2008) Genomics of cellulosic biofuels. Nature 454:841-845. https:// doi.org/10.1038/nature07190

Sánchez-Ramírez E, Quiroz-Ramírez JJ, Segovia-Hernández JG et al (2015) Process alternatives for biobutanol purification: design and optimization. Ind Eng Chem Res 54:351-358. https://doi.org/10.1021/ie503975g

Schläfle S, Senn T, Gschwind P, Kohlus R (2017) Feasibility and energetic evaluation of air stripping for bioethanol production. Bioresour Technol 231:109-115. https://doi.org/10.1016/j.biortech.2017.02.001

Simo M (2008) Pressure swing adsorption process for ethanol dehydration. University of Buffalo, NY, USA

Simo M (2013) Dehydration of ethanol using pressure swing adsorption. In: Ramaswamy S, Huang HJ, Ramarao BV (eds) Separation and purification technologies in biorefineries. Wiley, Hoboken. https://doi. org/10.1002/9781118493441.ch19

Singh R, Shukla A, Tiwari S, Srivastava M (2014) A review on delignification of lignocellulosic biomass for enhancement of ethanol production potential. Renew Sustain Energy Rev 32:713-728. https://doi.org/10.1016/j. rser.2014.01.051

Skarstrom CW (1960) Method and apparatus for fractionating gaseous mixtures by adsorption. US patent, Patent no. US2944627A

Sun N, Okoye C, Niu CH, Wang H (2007) Adsorption of water and ethanol by biomaterials. Int J Green Energy 4:623-634. https://doi. org/10.1080/15435070701665396

Tajallipour M, Niu C, Dalai A (2013) Ethanol dehydration in a pressure swing adsorption process using canola meal. Energy Fuels 27:6655-6664. https ://doi.org/10.1021/ef400897e
Tye YY, Lee KT, Abdullah WNW, Leh CP (2016) The world availability of nonwood lignocellulosic biomass for the production of cellulosic ethanol and potential pretreatments for the enhancement of enzymatic saccharification. Renew Sustain Energy Rev 60:155-172. https://doi.org/10.1016/j. rser.2016.01.072

Union of Concerned Scientists (2012) The promise of biomass: clean power and fuel — if handled right. In: Union Concerned Sci. http://www.ucsus a.org/clean_vehicles/smart-transportation-solutions/cleaner_fuels/ethan ol-and-other-biofuels/biomass-energy-resources.html

Vane LM (2008) Separation technologies for the recovery and dehydration of alcohols from fermentation broths. Biofuels Bioprod Biorefin 2:553-588. https://doi.org/10.1002/bbb.108

Vareli G, Demertzis PG, Akrida-Demertzi K (2000) Effect of regeneration thermal treatment of cellulosic and starchy materials on their capacity to separate water and ethanol. J Cereal Sci 31:147-154. https://doi. org/10.1006/jcrs.1999.0255

Wang Y, Gong C, Sun J et al (2010) Separation of ethanol/water azeotrope using compound starch-based adsorbents. Bioresour Technol 101:61706176. https://doi.org/10.1016/j.biortech.2010.02.102

World Fuel Ethanol Production (2017) Renewable Fuels Association, Industry statistics. https://ethanolrfa.org/resources/industry/statistics/. Accessed 5 Jan 2018

Wu P, Gao H, Sun J et al (2015) Characterization of biomass adsorbent ZSG-1 through isopropanol and water azeotrope dehydration. Chem Eng Commun 202:252-259. https://doi.org/10.1080/00986445.2013.798730

Xu YM, Tang YP, Chung T-S et al (2018) Polyarylether membranes for dehydration of ethanol and methanol via pervaporation. Sep Purif Technol 193:165-174. https://doi.org/10.1016/j.seppur.2017.11.004

Xue C, Zhao J-B, Chen L-J et al (2014) Integrated butanol recovery for an advanced biofuel: current state and prospects. Appl Microbiol Biotechnol 98:3463-3474. https://doi.org/10.1007/s00253-014-5561-6

Yan B, Niu CH (2017a) Modeling and site energy distribution analysis of levofloxacin sorption by biosorbents. Chem Eng J 307:631-642. https://doi. org/10.1016/j.cej.2016.08.065

Yan B, Niu CH (2017b) Pre-treating biosorbents for purification of bioethanol from aqueous solution. Int J Green Energy 14:245-252. https://doi. org/10.1080/15435075.2016.1254087

Zhao L, Lyu X, Wang W et al (2017) Comparison of heterogeneous azeotropic distillation and extractive distillation methods for ternary azeotrope ethanol/toluene/water separation. Comput Chem Eng 100:27-37. https ://doi.org/10.1016/j.compchemeng.2017.02.007

\section{Submit your manuscript to a SpringerOpen ${ }^{\odot}$ journal and benefit from:}

- Convenient online submission

- Rigorous peer review

- Open access: articles freely available online

- High visibility within the field

Retaining the copyright to your article

Submit your next manuscript at springeropen.com 